\title{
Arginine vasopressin modulates electrical activity and calcium homeostasis in pulmonary vein cardiomyocytes
}

\author{
Jen-Hung Huang ${ }^{1,2}$, Yao-Chang Chen ${ }^{3}$, Yen-Yu Lü ${ }^{4,5}$, Yung-Kuo Lin ${ }^{1,2}$, Shih-Ann Chen ${ }^{6}$ and Yi-Jen Chen ${ }^{1,78^{*}}$
}

\begin{abstract}
Background: Atrial fibrillation (AF) frequently coexists with congestive heart failure (HF) and arginine vasopressin (AVP) V1 receptor antagonists are used to treat hyponatremia in HF. However, the role of AVP in HF-induced AF still remains unclear. Pulmonary veins (PVs) are central in the genesis of AF. The purpose of this study was to determine if AVP is directly involved in the regulation of PV electrophysiological properties and calcium $\left(\mathrm{Ca}^{2+}\right)$ homeostasis as well as the identification of the underlying mechanisms.
\end{abstract}

Methods: Patch clamp, confocal microscopy with Fluo-3 fluorescence, and Western blot analyses were used to evaluate the electrophysiological characteristics, $\mathrm{Ca}^{2+}$ homeostasis, and $\mathrm{Ca}^{2+}$ regulatory proteins in isolated rabbit

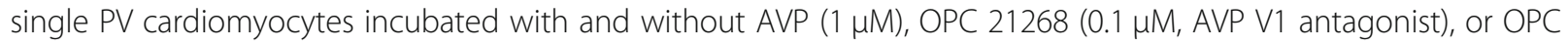
41061 (10 nM, AVP V2 antagonist) for 4-6 h.

Results: AVP (0.1 and $1 \mu \mathrm{M})$-treated PV cardiomyocytes had a faster beating rate (108 to 152\%) than the control cells. AVP $(1 \mu \mathrm{M})$ treated PV cardiomyocytes had higher late sodium $\left(\mathrm{Na}^{+}\right)$and $\mathrm{Na}^{+} / \mathrm{Ca}^{2+}$ exchanger $(\mathrm{NCX})$ currents than control PV cardiomyocytes. AVP $(1 \mu \mathrm{M})$ treated PV cardiomyocytes had smaller $\mathrm{Ca}^{2+}{ }_{i}$ transients, and sarcoplasmic reticulum (SR) $\mathrm{Ca}^{2+}$ content as well as higher $\mathrm{Ca}^{2+}$ leak. However, combined AVP $(1 \mu \mathrm{M})$ and OPC $21268(0.1 \mu \mathrm{M})$ treated PV cardiomyocytes had a slower PV beating rate, larger $\mathrm{Ca}^{2+}{ }_{i}$ transients and SR $\mathrm{Ca}^{2+}$ content, smaller late $\mathrm{Na}^{+}$and NCX currents than AVP $(1 \mu \mathrm{M})$-treated PV cardiomyocytes. Western blot experiments showed that AVP $(1 \mu \mathrm{M})$ treated PV cardiomyocytes had higher expression of NCX and p-CaMKIl, and a higher ratio of pCaMKII/CaMKII.

Conclusions: AVP increases PV arrhythmogenesis with dysregulated $\mathrm{Ca}^{2+}$ homeostasis through vasopressin $\mathrm{V} 1$ signaling.

Keywords: Atrial fibrillation, Arginine vasopressin, Calcium homeostasis, Pulmonary vein

\section{Introduction}

Arginine vasopressin (AVP), is a nonapeptide produced by the posterior pituitary gland, mainly synthesized and secreted in the hypothalamus. AVP binds to its receptor to promote vasoconstriction through modulation of adenosine triphosphate-sensitive potassium channel function and nitric oxide $(\mathrm{NO})$ production, and enhances the

\footnotetext{
* Correspondence: yjchen@tmu.edu.tw

${ }^{1}$ Division of Cardiovascular Medicine, Department of Internal Medicine, Wan Fang Hospital, Taipei Medical University, 111 Hsin-Lung Road, Sec. 3, Taipei 116, Taiwan

${ }^{7}$ Graduate Institute of Clinical Medicine, College of Medicine, Taipei Medical University, Taipei, Taiwan

Full list of author information is available at the end of the article
}

vascular response to catecholamines [1]. AVP is an essential stress hormone released in response to hyperosmolarity, hypotension, or hypovolemia [2]. AVP has several physiological functions, including V1a receptor-mediated regulation of blood pressure and V2 receptor-mediated control of body water [3]. AVP has been clinically proven to be related to the severity of heart failure $(\mathrm{HF})[4,5]$. AVP V2 receptor antagonists are also used to treat hyponatremia associated with HF [6]. OPC 41061, AVP V2 receptor antagonist, had been demonstrated to suppress multiple potassium currents on GH3 (a rat clonal pituitary cell line) [7]. Additionally, AVP is a nonsympathomimetic vasopressor, which causes vasoconstriction via activation 
of the V1 vasopressin receptor [8]. The V1a receptor, associated with a $G_{\mathrm{q} / 11}$ protein, hydrolyses phosphatidylinositol 4,5-bisphosphate into inositol trisphosphate $\left(\mathrm{IP}_{3}\right)$ and diacylglycerol (DAG) via the activation of phospholipase $\mathrm{C}$ [9]. $\mathrm{IP}_{3}$ induces calcium $\left(\mathrm{Ca}^{2+}\right)$ release from the sarcoplasmic reticulum (SR) $[10,11]$, whereas DAG activates protein kinase $\mathrm{C}$, which opens voltage-gated $\mathrm{Ca}^{2+}$ channels and closes potassium channels [11].

HF and atrial fibrillation (AF) are closely interrelated with sharing similar risk factors and pathophysiology [12]. Patients with concomitant HF and AF suffer from even worse symptoms and poorer prognosis. Centrally liberated AVP increases sympathetic outflow to the cardiovascular system and may increase the risk of arrhythmia and sudden death [13]. However, the relationship between AF and AVP has not been clearly elucidated. Earlier studies showed that increased AF occurrence in patients with postoperative vasoplegic shock more frequently experienced new AF with prolonged AVP therapy $[14,15]$.

Pulmonary vein (PV) myocardium consists of a mixture of working cardiomyocytes and pacemaker cells. It plays a critical role in the genesis and maintenance of AF [16]. PVs are important sources of ectopic beats that can initiate paroxysmal AF and ectopic atrial tachycardia [17]. PV cardiomyocytes exhibit distinct electrophysiological characteristics that include spontaneous activity and triggers, which may contribute to PV arrhythmogenesis [18]. Abnormal $\mathrm{Ca}^{2+}$ regulation plays a pivotal role in PV electrical activity. Late sodium currents $\left(\mathrm{I}_{\mathrm{Na}-\text { late }}\right)$ and intracellular $\mathrm{Ca}^{2+}\left(\mathrm{Ca}^{2+}{ }_{\mathrm{i}}\right)$ dynamics play an important role in PV arrhythmogenesis and HF. Dysregulated $\mathrm{Ca}^{2+}$ homeostasis, and increased $\mathrm{Ca}^{2+}$ spark frequency promotes arrhythmogenesis of PV cardiomyocytes in HF, which may play an important role in the development of AF [19]. Interestingly, in vitro and in vivo studies showed that AVP produces relatively less vasoconstriction in pulmonary circulation [20,21]. However, the role of AVP in PV arrhythmogenesis was not clear. Since AVP signaling may modulate $\mathrm{Ca}^{2+}$ homeostasis, we suggest that enhanced AVP might contribute to PV arrhythmogenesis. The aim of this study was an evaluation of the effects of AVP on the PV electrophysiological characteristics and $\mathrm{Ca}^{2+}$ handling and an investigation of the potential mechanisms.

\section{Materials and methods}

Isolation of single cardiomyocytes and cell preparations

The investigation was approved by the local ethics review board and conformed to the institutional Guide for the Care and Use of Laboratory Animals published by the US National Institutes of Health. Male rabbits $(2.0 \sim 3.0 \mathrm{~kg})$ were euthanized using intramuscular injections of a mixture of Zoletil $50(10 \mathrm{mg} / \mathrm{kg})$ and xylazine $(5 \mathrm{mg} / \mathrm{kg})$ with an overdose of isoflurane $(5 \%$ in oxygen) from a precision vaporizer. Single cardiomyocytes from rabbit PVs were enzymatically dissociated through a previously described procedure [18]. In brief, a mid-line thoracotomy was performed, and the heart and lungs were removed. PVs were perfused in a retrograde manner via polyethylene tubing cannulated through the aorta and left ventricle into the left atrium. The free end of the polyethylene tube was connected to a Langendroff perfusion column for perfusion with oxygenated normal Tyrode's solution (containing (in $\mathrm{mM}$ ): $\mathrm{NaCl} 137, \mathrm{KCl} 5.4, \mathrm{CaCl}_{2} 1.8, \mathrm{MgCl}_{2}$ 0.5, HEPES 10 and glucose 11; with $\mathrm{pH}$ adjusted to 7.4 by titration with $1 \mathrm{~N}$ $\mathrm{NaOH}$. The perfusate was replaced with oxygenated $\mathrm{Ca}^{2+}$-free Tyrode's solution containing $300 \mathrm{units} / \mathrm{ml} \mathrm{col-}$ lagenase (Sigma Type I) and 0.25 units $/ \mathrm{ml}$ of protease (Sigma, Type XIV) for 8 12 min. Proximal PVs were cut away from the atrium and lung, and were gently shaken in $5 \sim 10 \mathrm{ml}$ of $\mathrm{Ca}^{2+}$-free oxygenated Tyrode's solution until single cardiomyocytes were obtained. The solution was then gradually changed to oxygenated normal Tyrode's solution. Cells were allowed to stabilize in the bath for at least $30 \mathrm{~min}$ before the experiments were started. Single cardiomyocytes with spontaneous activity were identified by the presence of constant beating during perfusion with Tyrode's solution. PV cardiomyocytes were incubated without (control) and with AVP (0.1 and $1 \mu \mathrm{M})$, AVP $(1 \mu \mathrm{M})$ combined with or without OPC 21268 (AVP V1 receptor antagonist, $0.1 \mu \mathrm{M}$ ), OPC 41061 (AVP V2 receptor antagonist, $10 \mathrm{nM}$ ) [22, 23] for $4 \sim 6 \mathrm{~h}$ before patch clamp or western blot.

\section{Patch clamp experiments}

A whole-cell patch-clamp was used to record ionic currents and action potentials (APs) in isolated PV cardiomyocytes with an Axopatch 1D amplifier (Axon Instruments, Foster City, CA, USA) at $35^{\circ} \mathrm{C} \pm 1$ after rupture or perforation (for L-type $\mathrm{Ca}^{2+}$ current, $\mathrm{I}_{\mathrm{Ca}-\mathrm{L}}$ ) at an approximately similar period, as previously described [18]. The micropipette resistance was $3 \sim 5 \mathrm{M} \Omega$. A small hyperpolarizing step from a holding potential of -50 $\mathrm{mV}$ to a testing potential of $-55 \mathrm{mV}$ for $80 \mathrm{~ms}$ was delivered at the start of each experiment. The area under the capacitive current curve was divided by the applied voltage step to obtain the total cell capacitance. Normally, 60\% 80\% series resistance (Rs) was electronically compensated. APs were recorded in the current-clamp mode and ionic currents in the voltage-clamp mode. Spontaneous beating rate was defined as the constant occurrence of spontaneous APs in the absence of any electrical stimuli. APs were analyzed for maximum diastolic potential (MDP), amplitude (APA), threshold potential (the inflection point on the rising phase of 
action potential) [24, 25], early and late diastolic depolarization (linear and non-linear components of the interval between MDP and threshold potential) [26, 27], and $\mathrm{AP}$ duration (APD) at 75,50 and $20 \%$ repolarization of the amplitude $\left(\mathrm{APD}_{75}, \mathrm{APD}_{50}\right.$, and $\left.\mathrm{APD}_{20}\right)$ [28].

Micropipettes were filled with a solution containing (in mM) CsCl 130, $\mathrm{MgCl}_{2}$ 1, MgATP 5, HEPES 10, $\mathrm{Na}_{2}$ GTP 0.1 , and $\mathrm{Na}_{2}$ phosphocreatine 5 , titrated to a $\mathrm{pH}$ of 7.2 with $\mathrm{CsOH}$ for the experiments on the $\mathrm{I}_{\mathrm{Ca}-\mathrm{L}}$; with a solution containing (in $\mathrm{mM}$ ) $\mathrm{NaCl} 20, \mathrm{CsCl} 110, \mathrm{MgCl}_{2} 0.4$, $\mathrm{CaCl}_{2}$ 1.75, tetraethylammonium chloride (TEA-Cl) 20, BAPTA 5, glucose 5, MgATP 5, and HEPES 10, titrated to a pH of 7.25 with $\mathrm{CsOH}$ for experiments on the $\mathrm{Na}^{+}$/ $\mathrm{Ca}^{2+}$ exchanger (NCX) current; and with a solution containing (in mM) $\mathrm{CsCl} 130, \mathrm{Na}_{2} \mathrm{ATP} 4, \mathrm{MgCl}_{2}$ 1, EGTA 10 , and HEPES 5 at a pH of 7.3 with $\mathrm{NaOH}$ for the $\mathrm{I}_{\mathrm{Na} \text {-Late; }}$; with a solution containing (in $\mathrm{mM}$ ) $\mathrm{KCl} 20, \mathrm{~K}$ aspartate 110, $\mathrm{MgCl}_{2}$ 1, MgATP 5, HEPES 10, EGTA 0.5, $\mathrm{Na}_{2}$ GTP 0.1 , and $\mathrm{Na}_{2}$ phosphocreatine 5 , titrated to a $\mathrm{pH}$ of 7.2 with $\mathrm{KOH}$ for experiments on the AP.

The $\mathrm{I}_{\mathrm{Na} \text {-Late }}$ was recorded at room temperature with an external solution containing (in $\mathrm{mM}$ ): $\mathrm{NaCl} 130, \mathrm{CsCl} 5$, $\mathrm{MgCl}_{2} 1, \mathrm{CaCl}_{2} 1, \mathrm{HEPES} 10$, and glucose 10 at a $\mathrm{pH}$ of 7.4 with $\mathrm{NaOH}$ by a step/ramp protocol $(-100 \mathrm{mV}$ stepped to $+20 \mathrm{mV}$ for $100 \mathrm{~ms}$, then ramped back to $100 \mathrm{mV}$ over $100 \mathrm{~ms}$ ) to enhance $\mathrm{I}_{\mathrm{Na}-\text { Late }}$ since the nonequilibrium gating gives rise to a fast recovery of the $\mathrm{Na}^{+}$ channel from inactivated state and reactivation during repolarization ramp [29]. The external solution containing $\mathrm{CaCl}_{2}$ has been shown to block all movement of monovalent ions through $\mathrm{Na}^{+}$channels, which may avoid persistent $\mathrm{Ca}^{2+}$ current through $\mathrm{Na}^{+}$channels [30]. The application of tetrodotoxin $(30 \mu \mathrm{M})$ results inhibition of larger fraction of the plateau current of the $\mathrm{Na}^{+}$current, which has been shown to dissect the full measure of $\mathrm{I}_{\mathrm{Na}-}$ Late [31]. The $\mathrm{I}_{\mathrm{Na}-\text { late }}$ was measured as the tetrodotoxin $(30 \mu \mathrm{M})$-sensitive part of the current traces obtained when the voltage was ramped back to $-100 \mathrm{Mv}$ [32].

The $\mathrm{I}_{\mathrm{Ca}-\mathrm{L}}$ was measured as an inward current during depolarization from a holding potential of $-50 \mathrm{mV}$ to test potentials ranging from -40 to $+60 \mathrm{mV}$ in $10 \mathrm{mV}$ steps for $300 \mathrm{~ms}$ at a frequency of $0.1 \mathrm{~Hz}$ using a perforated patch clamp with amphotericin $\mathrm{B} . \mathrm{NaCl}$ and $\mathrm{KCl}$ in the external solution were replaced with TEA-Cl and $\mathrm{CsCl}$. To avoid run-down effect (the spontaneous decrease of voltage-activated current after onset of dialysis by the pipette solution) [33], the $\mathrm{I}_{\mathrm{Ca}-\mathrm{L}}$ was measured at 5 15 min after perforating the membrane patch in each PV cardiomyocyte.

The NCX current was elicited by test pulses of between -100 and $+100 \mathrm{mV}$ from a holding potential of $40 \mathrm{mV}$ for $300 \mathrm{~ms}$ at a frequency of $0.1 \mathrm{~Hz}$. The amplitudes of the NCX current were measured as $10 \mathrm{mM}$ nickel-sensitive currents. The external solution (in $\mathrm{mM}$ ) consisted of $\mathrm{NaCl} \mathrm{140,} \mathrm{CaCl}_{2} 2, \mathrm{MgCl}_{2} 1$, HEPES 5, and glucose 10 with a $\mathrm{pH}$ of 7.4, and contained strophanthidin $(10 \mu \mathrm{M})$, nitrendipine $(10 \mu \mathrm{M})$, and niflumic acid $(100 \mu \mathrm{M})$.

\section{Measurement of intracellular and SR calcium content}

As described previously, PV cardiomyocytes were loaded with fluorescent $\mathrm{Ca}^{2+}(10 \mu \mathrm{M}$, fluo-3/AM) for $30 \mathrm{~min}$ at room temperature [34]. The Fluo-3 fluorescence was excited using the 488-nm line of an argon ion laser and emission was recorded at $>515 \mathrm{~nm}$. Cells were repetitively scanned at 2-ms intervals. Fluorescence imaging was performed with a laser scanning confocal microscope (Zeiss LSM 510, Carl Zeiss, Jena, Germany) and an inverted microscope (Axiovert 100, Carl Zeiss). The fluorescent signals were corrected for variations in dye concentrations by normalizing the fluorescence $(F)$ against the baseline fluorescence $\left(F_{0}\right)$, to obtain reliable information about transient intracellular $\mathrm{Ca}^{2+}\left(\mathrm{Ca}^{2+}{ }_{\mathrm{i}}\right)$ changes from baseline values $\left(\mathrm{F}-\mathrm{F}_{0}(\Delta \mathrm{F}) / \mathrm{F}_{0}\right)$ and to exclude variations in the fluorescence intensity by different volumes of injected dye. The $\mathrm{Ca}^{2+}{ }_{\mathrm{i}}$ transient, peak systolic $\mathrm{Ca}^{2+}{ }_{\mathrm{i}}$, and diastolic $\mathrm{Ca}^{2+}{ }_{\mathrm{i}}$ were measured during spontaneous beating and pacing with a $2-\mathrm{Hz}$ field-stimulation with $10-\mathrm{ms}$ twicethreshold strength square-wave pulses. The $\mathrm{SR} \mathrm{Ca}^{2+}$ content was estimated by the rapid addition of $20 \mathrm{mM}$ caffeine after electric stimulation at $2 \mathrm{~Hz}$ for at least $30 \mathrm{~s}$. The total SR $\mathrm{Ca}^{2+}$ content was determined from the peak amplitude of the caffeine-induced $\mathrm{Ca}^{2+}{ }_{\mathrm{i}}$ transients.

For the measurement of SR $\mathrm{Ca}^{2+}$ leak, $\mathrm{PV}$ cardiomyocytes were incubated with AVP $(1 \mu \mathrm{M})$ or AVP $(1 \mu \mathrm{M})$ plus KN$93 \mathrm{a} \mathrm{Ca}^{2+} /$ calmodulin-dependent protein kinase II, CaM$\mathrm{KII}$ inhibitor, $1 \mu \mathrm{M})$ for $4 \sim 6 \mathrm{~h}$ before experiments. PV cardiomyocytes were stimulated at $2 \mathrm{~Hz}$ in normal Tyrode's solution to bring the cellular $\mathrm{Ca}^{2+}$ content to a steady state. In the control condition, $\mathrm{Ca}^{2+}{ }_{\text {i }}$ was monitored while $0 \mathrm{Na}^{+}$, $0 \mathrm{Ca}^{2+}$ Tyrode's solution (without tetracaine) was perfused for a minimum of $20 \mathrm{~s}$. In the test condition, the superfusate was rapidly switched to $0 \mathrm{Na}^{+}, 0 \mathrm{Ca}^{2+}$ Tyrode's solution with $1 \mathrm{mM}$ tetracaine after the last pulse for a minimum of $20 \mathrm{~s}$. Under this condition, the ryanodine receptor (RyR) is abruptly blocked and the $\mathrm{Ca}^{2+}$ leak can be measured as a drop in $\mathrm{Ca}^{2+}{ }_{\mathrm{i}}$.

\section{Western blot analysis}

Control and AVP $(1 \mu \mathrm{M})$-treated PV cardiomyocytes were centrifuged and washed with cold PBS, and lysed on ice for 30 min in RIPA buffer containing $50 \mathrm{mM}$ Tris, pH 7.4, 150 $\mathrm{mM} \mathrm{NaCl}, 1 \% \mathrm{NP} 40,0.5 \% \mathrm{Na}^{+}$deoxycholate, $0.1 \% \mathrm{Na}^{+}$dodecyl sulfate (SDS), and protease inhibitor cocktails (SigmaAldrich, St Louis, MO, USA). The protein concentration was determined using Bio-Rad protein assay reagent (BioRad, Hercules, CA, USA). Proteins were separated on 4\% $12 \%$ SDS-polyacrylamide gel by electrophoresis (PAGE) under reducing conditions and electrophoretically 
transferred to an equilibrated polyvinylidene difluoride membrane (Amersham Biosciences, Buckinghamshire, UK). All blots were probed with primary antibodies against NCX (Swant, Bellinzona, Switzerland), $\mathrm{Ca}^{2+} / \mathrm{cal}-$ modulin-dependent protein kinase II (CaMKII; Abcam, Cambridge, UK), pCaMKII at Thr 286, glyceraldehyde-3phosphate dehydrogenase (GAPDH) (MBL, Nagoya, Japan), AVP V1a receptor (AVPR1a, Biorbyt, Riverside, UK), AVP V2 receptor (AVPR2, Abbexa, Cambridge, UK), and all secondary antibodies conjugated with horseradish peroxidase. All bound antibodies were detected with an enhanced chemiluminescence detection system (Millipore, Billerica, MA, USA) and analyzed with AlphaEaseFC software. All targeted bands were normalized to GAPDH to confirm equal protein loading.

\section{Data and statistical analysis}

All continuous parameters were expressed as mean \pm the standard error of the mean (SEM). An unpaired t-test, one-way or two-way analysis of variance (ANOVA) with a Duncan post-hoc test was used to compare differences between the groups. A $P$ value of $<0.05$ was considered statistically significant.

\section{Results}

\section{Effects of AVP and AVP receptor antagonists on PV} electrical activity, and AVP receptor expressions on PV cardiomyocytes

As shown in Fig. 1a, AVP $(0.1$ and $1 \mu \mathrm{M})$-treated PV cardiomyocytes had a faster dose dependent beating rate than control PV cardiomyocytes by 4 and 37\% respectively. AVP $(1 \mu \mathrm{M})$-treated PV cardiomyocytes had a greater slope of late diastolic depolarization and a shorter beating rate interval than other groups. The AP features, threshold potential, and the slope of early diastolic depolarization of PV cardiomyocytes were similar among different groups (Table 1).

The beating rate in OPC $21268(0.1 \mu \mathrm{M})$ or OPC41061 (10 nM)-treated PV cardiomyocytes was similar to that in control PV cardiomyocytes. However, combined OPC $21268(0.1 \mu \mathrm{M})$ and AVP $(1 \mu \mathrm{M})$-treated PV cardiomyocytes had similar beating rate and the slope of late diastolic depolarization as compared to the control (Table 1), suggesting that OPC $21268(0.1 \mu \mathrm{M})$ may attenuate the effects of AVP on PV electrical activity. The beating rate in combined OPC $41061(10 \mathrm{nM})$ and AVP $(1 \mu \mathrm{M})$-treated PV cardiomyocytes was similar to that in AVP $(1 \mu \mathrm{M})$-treated PV cardiomyocytes. This finding suggests that OPC $41061(10 \mathrm{nM})$ did not change the electrophysiological effects of AVP on PV cardiomyocytes (Fig. 1a). Moreover, western blot expressions showed that both AVP V1 and V2 receptors were expressed in rabbit PV cardiomyocytes (Fig. 1b).

\section{Effect of AVP and AVP receptor antagonists on ionic currents of PV cardiomyocytes}

Figure 2 shows that AVP $(1 \mu \mathrm{M})$-treated PV cardiomyocytes had a $58 \%$ larger $\mathrm{I}_{\mathrm{Na}-\text { Late }}$ than the control cells. As shown in Fig. 3, AVP $(1 \mu \mathrm{M})$-treated PV cardiomyocytes had larger increases in the forward and reverse modes of
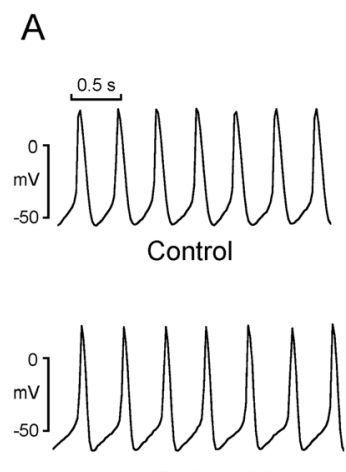

AVP $0.1 \mu \mathrm{M}$

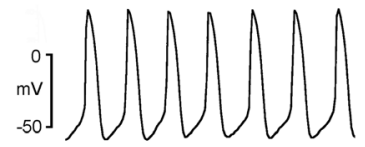
OPC $21268100 \mathrm{nM}$

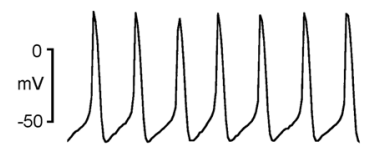
AVP $1 \mu \mathrm{M}+$ OPC $21268100 \mathrm{nM}$
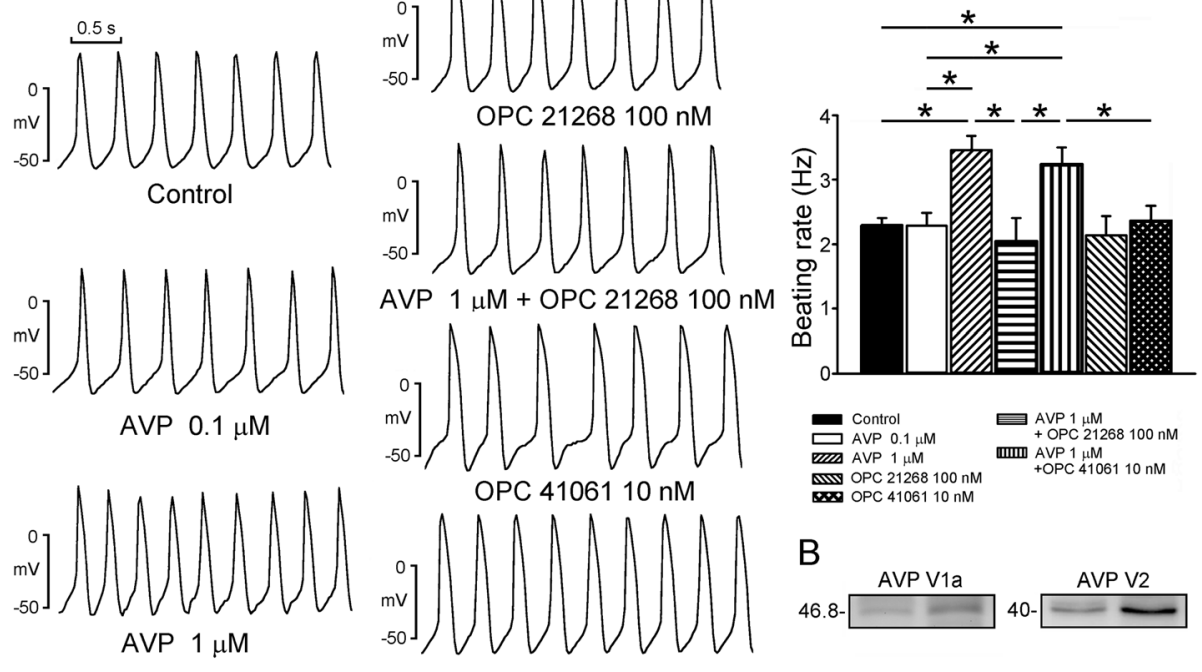

B

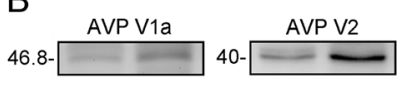

AVP $1 \mu \mathrm{M}+$ OPC $4106110 \mathrm{nM}$

Fig. 1 Effects of arginine vasopressin (AVP) and its antagonist OPC 21268 and OPC 41061 on the spontaneous activity of pulmonary vein (PV) cardiomyocytes. a Examples and average data of spontaneous activity from control $(n=12)$ and from PV cardiomyocytes treated with either AVP $(0.1 \mu \mathrm{M}, n=11)$, AVP $(1 \mu \mathrm{M}, n=13)$, OPC $21268(0.1 \mu \mathrm{M}, n=10)$, AVP $(1 \mu \mathrm{M})$ plus OPC $21268(0.1 \mu \mathrm{M})(n=11)$, OPC $41061(10 \mathrm{nM}, n=10)$, or AVP $(1 \mu \mathrm{M})$ plus OPC $41061(10 \mathrm{nM})(n=12)$. b Expression of AVP V1a receptor (AVPR1a) and V2 receptor (AVPR2) on PV cardiomyocytes. ${ }^{*} P<0.05$ 
Table 1 Action potential (AP) parameters of pulmonary vein cardiomyocytes treated with or without (control) arginine vasopressin (AVP) and/or AVP receptor antagonist (V1,OPC 21268 and V2 OPC 41061)

\begin{tabular}{|c|c|c|c|c|c|c|c|c|c|}
\hline & $\begin{array}{l}\text { APA } \\
(\mathrm{mV})\end{array}$ & $\begin{array}{l}\mathrm{APD}_{75} \\
\text { (msec) }\end{array}$ & $\begin{array}{l}\mathrm{APD}_{50} \\
\text { (msec) }\end{array}$ & $\begin{array}{l}\mathrm{APD}_{20} \\
\text { (msec) }\end{array}$ & $\begin{array}{l}\text { Beating rate } \\
\text { interval (msec) }\end{array}$ & $\begin{array}{l}\text { EDD } \\
(\mathrm{mV} / \mathrm{msec})\end{array}$ & $\begin{array}{l}\mathrm{LDD} \\
(\mathrm{mV} / \mathrm{msec})\end{array}$ & $\begin{array}{l}\mathrm{MDP} \\
(\mathrm{mV})\end{array}$ & $\mathrm{TP}(\mathrm{mV})$ \\
\hline Control, $(n=12)$ & $80 \pm 6$ & $140 \pm 13$ & $99 \pm 13$ & $54 \pm 8$ & $453 \pm 28$ & $0.13 \pm 0.05$ & $0.21 \pm 0.04$ & $-55 \pm 4$ & $-39 \pm 3$ \\
\hline $\operatorname{AVP}(0.1 \mu \mathrm{M}),(n=11)$ & $82 \pm 8$ & $164 \pm 18$ & $109 \pm 16$ & $65 \pm 11$ & $432 \pm 35^{\#}$ & $0.08 \pm 0.01$ & $0.33 \pm 0.05^{\#}$ & $-60 \pm 2$ & $-32 \pm 5$ \\
\hline $\operatorname{AVP}(1 \mu \mathrm{M}),(n=13)$ & $71 \pm 7$ & $121 \pm 12$ & $82 \pm 8$ & $43 \pm 5$ & $305 \pm 21^{*}$ & $0.09 \pm 0.01$ & $0.43 \pm 0.06^{*}$ & $-53 \pm 3$ & $-32 \pm 2$ \\
\hline $\begin{array}{l}\operatorname{AVP}(1 \mu \mathrm{M})+\mathrm{OPC} 21268(0.1 \mu \mathrm{M}) \\
(n=11)\end{array}$ & $80 \pm 6$ & $131 \pm 8$ & $91 \pm 7$ & $48 \pm 4$ & $813 \pm 213^{\#}$ & $0.08 \pm 0.01$ & $0.25 \pm 0.03^{\#}$ & $-56 \pm 4$ & $-36 \pm 3$ \\
\hline $\begin{array}{l}\operatorname{AVP}(1 \mu M)+O P C 41061(10 n M) \\
(n=12)\end{array}$ & $90 \pm 4$ & $142 \pm 4$ & $104 \pm 3$ & $58 \pm 4$ & $329 \pm 22^{*}$ & $0.11 \pm 0.02$ & $0.37 \pm 0.02^{*}$ & $-54 \pm 5$ & $-36 \pm 3$ \\
\hline OPC $21268(0.1 \mu \mathrm{M}),(n=10)$ & $90 \pm 4$ & $148 \pm 13$ & $97 \pm 10$ & $57 \pm 8$ & $581 \pm 100$ & $0.09 \pm 0.02$ & $0.29 \pm 0.03$ & $-62 \pm 3$ & $-34 \pm 3$ \\
\hline OPC $41061(10 \mathrm{nM}),(n=10)$ & $94 \pm 4$ & $158 \pm 9$ & $118 \pm 8$ & $70 \pm 5$ & $468 \pm 52^{\S}$ & $0.09 \pm 0.01$ & $0.24 \pm 0.04^{\S}$ & $-59 \pm 2$ & $-30 \pm 3$ \\
\hline
\end{tabular}

$\mathrm{APD}_{75}, \mathrm{APD}_{50}$, and $\mathrm{APD}_{20}=\mathrm{AP}$ duration at 75, 50 and 20\% repolarization of the amplitude, EDD Early diastolic depolarization, $L D D$ Late diastolic depolarization, MDP Maximum diastolic potential, TP Threshold potential. ${ }^{*} P<0.05$ vs Control, ${ }^{\#} P<0.05$ vs AVP $(1 \mu M),{ }^{\S} P<0.05$ OPC 41461 (10 nM) vs AVP ( $\left.1 \mu \mathrm{M}\right)+$ OPC $41461(10 \mathrm{nM})$

NCX current (by 202\% in the peak forward and 143\% in the peak reverse mode current elicited from -40 to $100 \mathrm{mV})$. However, control and AVP $(1 \mu \mathrm{M})$-treated PV cardiomyocytes had similar $\mathrm{I}_{\mathrm{Ca}-\mathrm{L}}$. Compared to the control, OPC $21268(0.1 \mu \mathrm{M})$ did not change the current density of $\mathrm{I}_{\mathrm{Na}-\text { Late }}$ and NCX of PV cardiomyocytes. However, OPC $21268(0.1 \mu \mathrm{M})$ can reverse the effects of AVP $(1 \mu \mathrm{M})$ on $\mathrm{I}_{\text {Late-Na }}$ and NCX of PV cardiomyocytes.

\section{Effects of AVP on calcium homeostasis}

As can be seen in Fig. 4, AVP $(1 \mu \mathrm{M})$-treated PV cardiomyocytes had smaller $\mathrm{Ca}^{2+}$ transients and caffeineinduced $\mathrm{Ca}^{2+}$ transients than the control by 59 and $60 \%$, which suggests they had stored less $\mathrm{Ca}^{2+}$. Similarly, spontaneous $\mathrm{Ca}^{2+}$ transients in AVP $(1 \mu \mathrm{M})$-treated PV cardiomyocytes $(n=20)$ were smaller than those in the control $(n=22)$ by $67 \% \quad(P<0.001)$. OPC 21268 $(0.1 \mu \mathrm{M})$-treated PV cardiomyocytes combined with or without $\operatorname{AVP}(1 \mu \mathrm{M})$ had similar $\mathrm{Ca}^{2+}$ transients and caffeine-induced $\mathrm{Ca}^{2+}$ transients to the control, suggesting that the effects of AVP $(1 \mu \mathrm{M})$ on $\mathrm{Ca}^{2+}$ transients and SR $\mathrm{Ca}^{2+}$ content can be attenuated by OPC 21258 . Moreover, AVP $(1 \mu \mathrm{M})$-treated PV cardiomyocytes had greater $\mathrm{Ca}^{2+}$ leak than the control, which was attenuated by the presence of $\mathrm{KN}-93(1 \mu \mathrm{M})$.

AVP $(1 \mu \mathrm{M})$-treated PV cardiomyocytes had larger protein expressions of NCX and p-CaMKII, but the protein expression of CaMKII was similar between the control and AVP $(1 \mu \mathrm{M})$-treated PV cardiomyocytes (Fig. 5). Compared to control, the ratios of p-CaMKII/ CaMKII were increased in AVP $(1 \mu \mathrm{M})$-treated PV cardiomyocytes.

\section{Discussion}

In this study, it was found for the first time, that AVP has direct effects on electrical activity and $\mathrm{Ca}^{2+}$ homeostasis in PV cardiomyocytes. AVP increased the PV beating rate with a dose-dependent response. The increased PV beating rate caused by AVP can be ameliorated by V1 receptor antagonist OPC 21268. OPC 21268 did not change PV electrophysiological properties or $\mathrm{Ca}^{2+}$ homeostasis, suggesting that AVP directly regulates PV spontaneous activity via V1 receptor signaling. Previous study had shown that OPC 41061 displayed an inhibitory effect on AVP-induced cAMP increasing and modulated intracellular $\mathrm{Ca}^{2+}$ at the concentration of 10 $\mathrm{nM}$ [23]. The $\mathrm{IC}_{50}$ values for OPC 41061-mediated inhibition of voltage-gated potassium currents ranged between 2 and $7 \mu \mathrm{M}$ in GH3 cells derived from rat pituitary tumors [7]. In addition, OPC 41061 at higher concentrations may have biological effects in renal ciliary function independent of its binding to V2 receptor [35]. Therefore, the presence of these vasopressin antagonists could potentially exert direct perturbations on the functional activities in different types of cells. The effect of vasopressin antagonists on PV arrhythmogenesis in vivo still remains to be further investigated. Previous studies have shown that AVP V1a and V2 receptor were expressed in human and rodent hearts [36-38]. Similarly, by western blot, this study found both AVP V1a and V2 receptors were expressed in rabbit PV cardiomyocytes. However, V2 receptor antagonist did not change the effects of AVP on PV spontaneous activity, suggesting that V2 receptor signaling may not contribute to the electrical effects of AVP on PV cardiomyocytes. Previous study was found that AVP at $1 \mu \mathrm{M}$ mobilized $60 \%$ of cell-associated $\mathrm{Ca}^{2+}$ and decreased protein synthesis by $50 \%$ within $20-30 \mathrm{~min}$ [39]. Since the concentration $(1 \mu \mathrm{M})$ used in this study was clinically relevant [39], our findings suggest that AVP may increase the potential risk of AF by escalating PV arrhythmogenesis.

We previously found that enhanced $\mathrm{I}_{\mathrm{Na} \text {-Late }}$ increases PV arrhythmogenesis [17]. In the present study, it was found that AVP-treated PV cardiomyocytes showed 
(a) Control
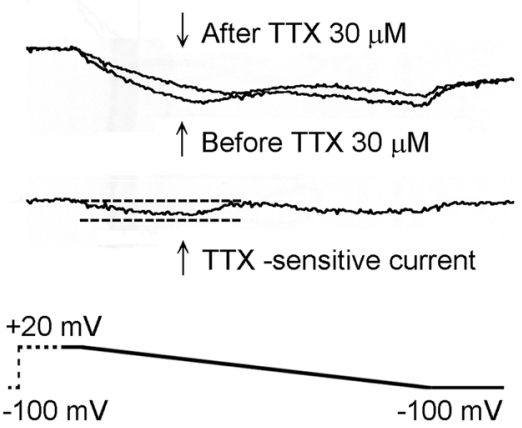

(b) AVP $1 \mu \mathrm{M}$

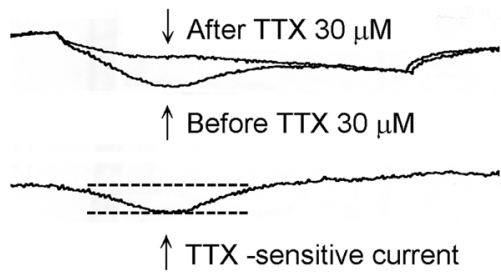

(c) OPC $21268100 \mathrm{nM}$
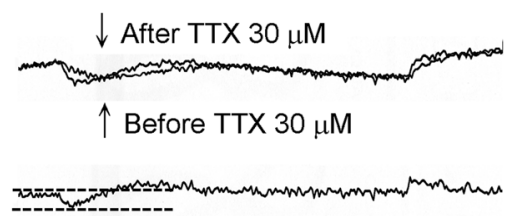

$\uparrow$ TTX -sensitive current

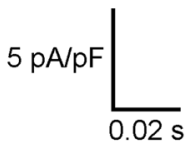

(d) AVP $1 \mu \mathrm{M}+$ OPC $21268100 \mathrm{nM}$
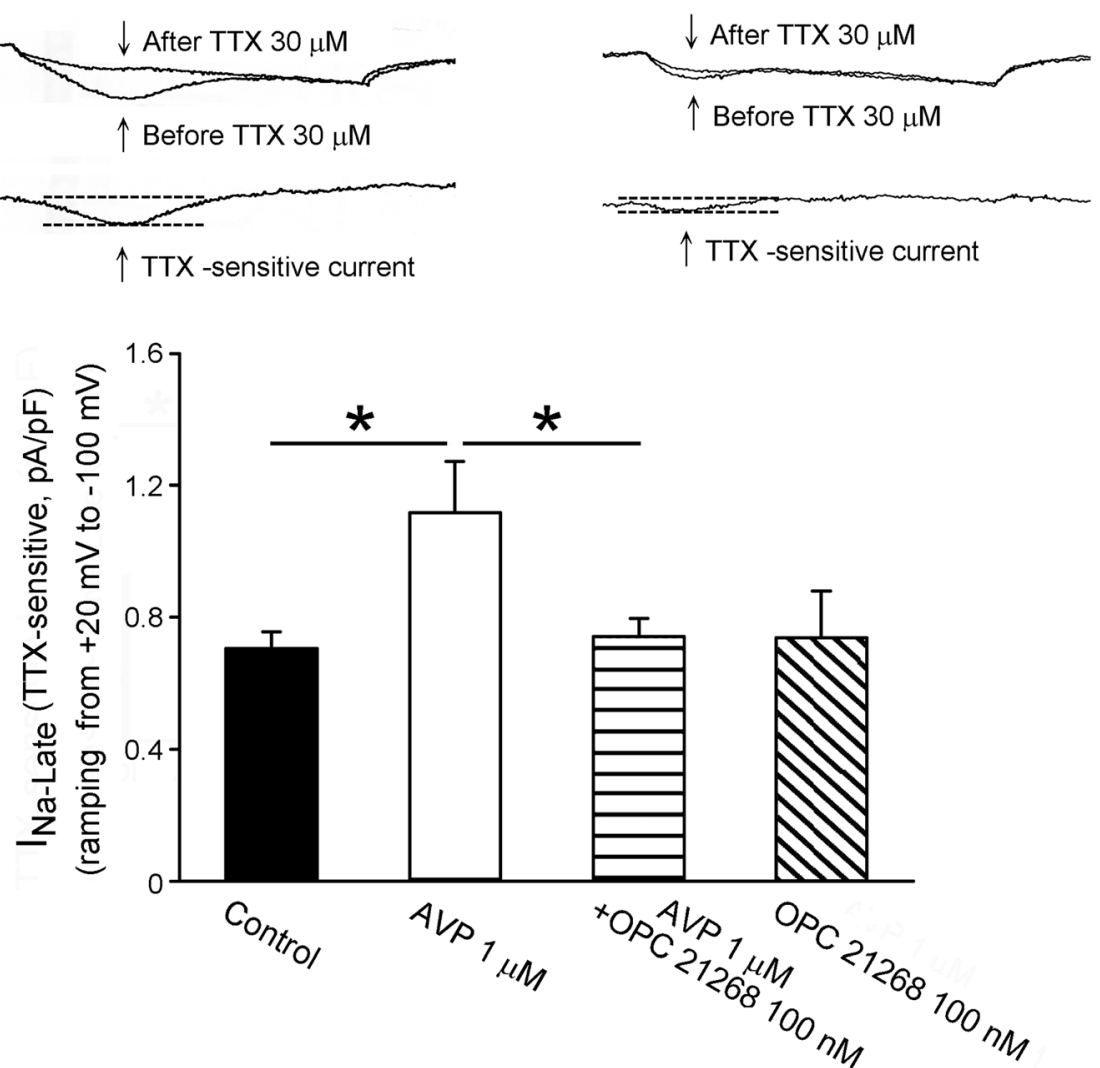

Fig. 2 Effects of arginine vasopressin (AVP) on the late sodium current ( $\left.\right|_{\text {Na-Late }}$ ) in pulmonary vein (PV) cardiomyocytes with and without AVP $(1 \mu \mathrm{M})$ or OPC $21268(0.1 \mu \mathrm{M})$. An example and the average data of the I $I_{\text {Na-Late }}$ from $(\mathbf{a})$ control $(n=12)$ and from PV cardiomyocytes treated with either (b) AVP (1 $\mu \mathrm{M}, n=12)$, (c) OPC $21268(0.1 \mu \mathrm{M}, n=9)$, or (d) AVP (1 $\mu \mathrm{M})$ plus OPC $21268(0.1 \mu \mathrm{M})(n=11)$. INa-Late was measured as the tetrodotoxin (TTX)-sensitive current during ramp pulse from $+20 \mathrm{mV}$ to $-100 \mathrm{mV}$. ${ }^{*} \mathrm{P}<0.05$

larger $\mathrm{I}_{\mathrm{Na}-\mathrm{Late}}$ and NCX than control PV cardiomyocytes. There are different methods of measuring the $\mathrm{I}_{\mathrm{Na} \text {-Late }}$ $[40,41]$. To dissect out $\mathrm{I}_{\mathrm{Na}-\mathrm{Late}}$ to a greater degree, we applied high concentration of tetrodotoxin $(30 \mu \mathrm{M})$ to block $\mathrm{Na}^{+}$current during a repolarizing voltage ramp $[29,31]$, which was expected to enhance $\mathrm{I}_{\mathrm{Na}-\mathrm{Late}}$. Increasing $\mathrm{I}_{\mathrm{Na}-\text { Late }}$ plays an important role in PV arrhythmogenesis by reducing the repolarization reserve. This opposes the repolarizing potassium currents and delays repolarization [42]. A reduction of the repolarization reserve in PV cardiomyocytes with elevated $\mathrm{I}_{\mathrm{Na} \text {-Late }}$ is more likely to develop early afterdepolarization in response to triggers [42]. $\mathrm{I}_{\mathrm{Na}-\text { Late }}$ would result in an increase of intracellular $\mathrm{Na}^{+}$concentration, which would activate reversed NCX [17], subsequently inducing the genesis of triggered activity [43]. We found that AVP-treated PV 

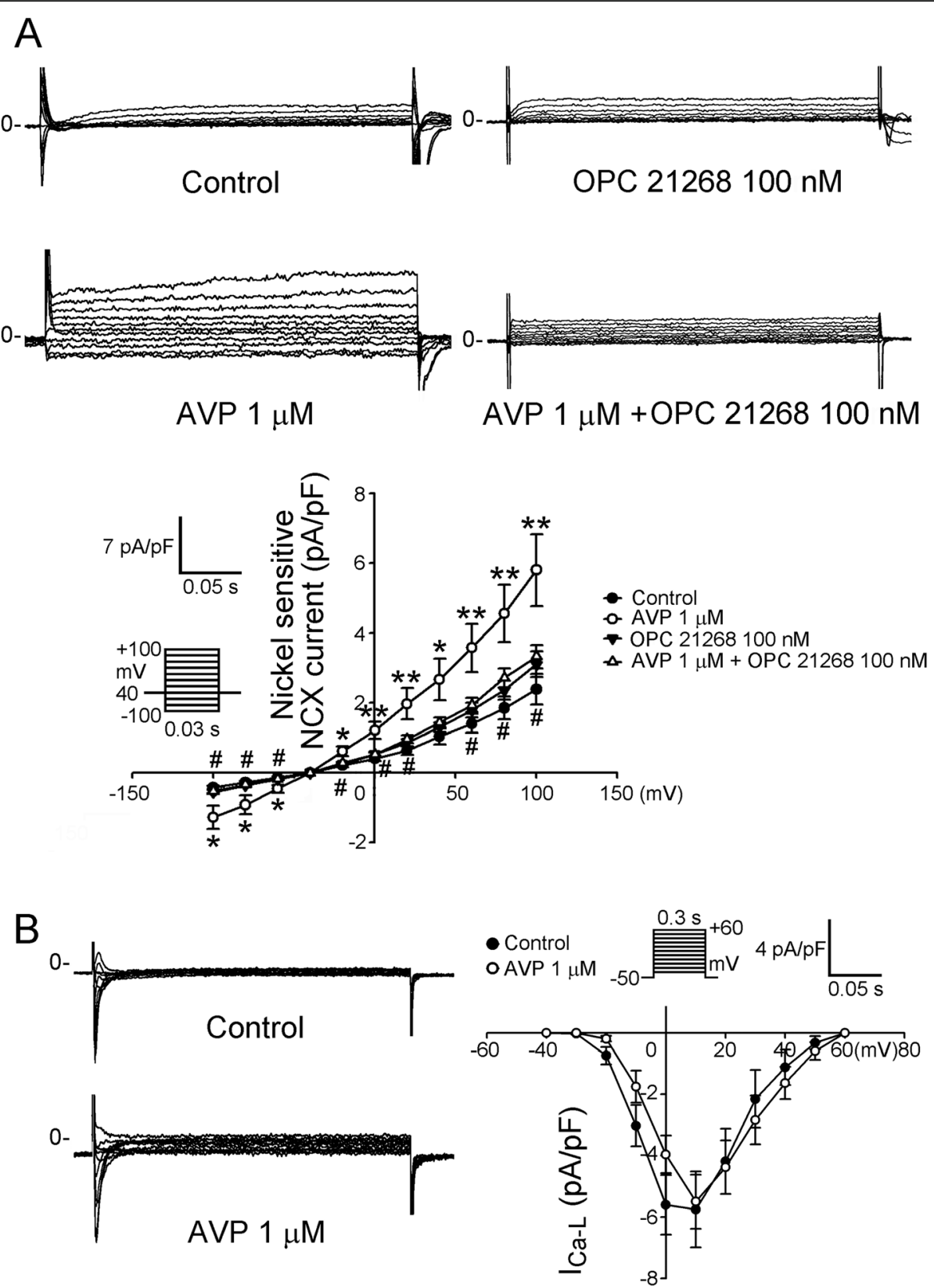

Fig. 3 Effects of arginine vasopressin (AVP) on the sodium/calcium exchanger (NCX), and L-type calcium ( $\left.\right|_{\text {Ca-L }}$ ) currents in pulmonary vein (PV) cardiomyocytes with and without AVP $(1 \mu \mathrm{M})$ or OPC $21268(0.1 \mu \mathrm{M})$. a An example and the average data of the NCX from control $(n=10)$ and PV cardiomyocytes treated with either AVP $(1 \mu \mathrm{M}, n=10)$, OPC $21268(0.1 \mu \mathrm{M}, n=9)$, or AVP (1 $\mu \mathrm{M})$ plus OPC $21268(0.1 \mu \mathrm{M})(n=10)$. b An example and the average data of the $\mathrm{I}_{\mathrm{Ca}-\mathrm{L}}$ from control $(n=9)$ and AVP $(1 \mu \mathrm{M})$-treated $(n=12) \mathrm{PV}$ cardiomyocytes. The inset in the current traces shows the clamp protocol. ${ }^{*} \mathrm{P}<0.05$ and ${ }^{* *} P<0.01$ Control vs AVP $(1 \mu \mathrm{M})$; \#P $<0.05$ AVP $(1 \mu \mathrm{M})$ vs AVP $(1 \mu \mathrm{M})$ combined with OPC 21268 (0.1 $\mu \mathrm{M}$

cardiomyocytes had increasing NCX, which may be caused by increasing $\mathrm{I}_{\mathrm{Na}-\mathrm{Late}}$ in addition to the increasing effect of AVP on NCX protein.

Cardiac $\mathrm{Ca}^{2+}$ homeostasis plays a crucial role in the maintenance of cardiac excitation and contraction, and significantly regulates cardiac contractility. Inhomeostasis of intracellular $\mathrm{Ca}^{2+}{ }_{\mathrm{i}}$ is common in a number of pathological conditions and contributes to arrhythmogenicity
$[44,45]$. The most recognized action of NCX is its $\mathrm{Ca}^{2+}$ removal function in forward mode at membrane voltages less than the equilibrium potential [46]. AVP enhanced forward mode NCX, which caused $\mathrm{Ca}^{2+}$ efflux, and resulted in a decrease of $\mathrm{Ca}^{2+}{ }_{\mathrm{i}}$ transients. This decrease in $\mathrm{Ca}^{2+}{ }_{\mathrm{i}}$ transients by AVP may contribute to the known adverse cardiac effects after AVP treatment [47]. Counteraction of the effects of AVP on $\mathrm{Ca}^{2+}{ }_{\mathrm{i}}$ transients and SR 


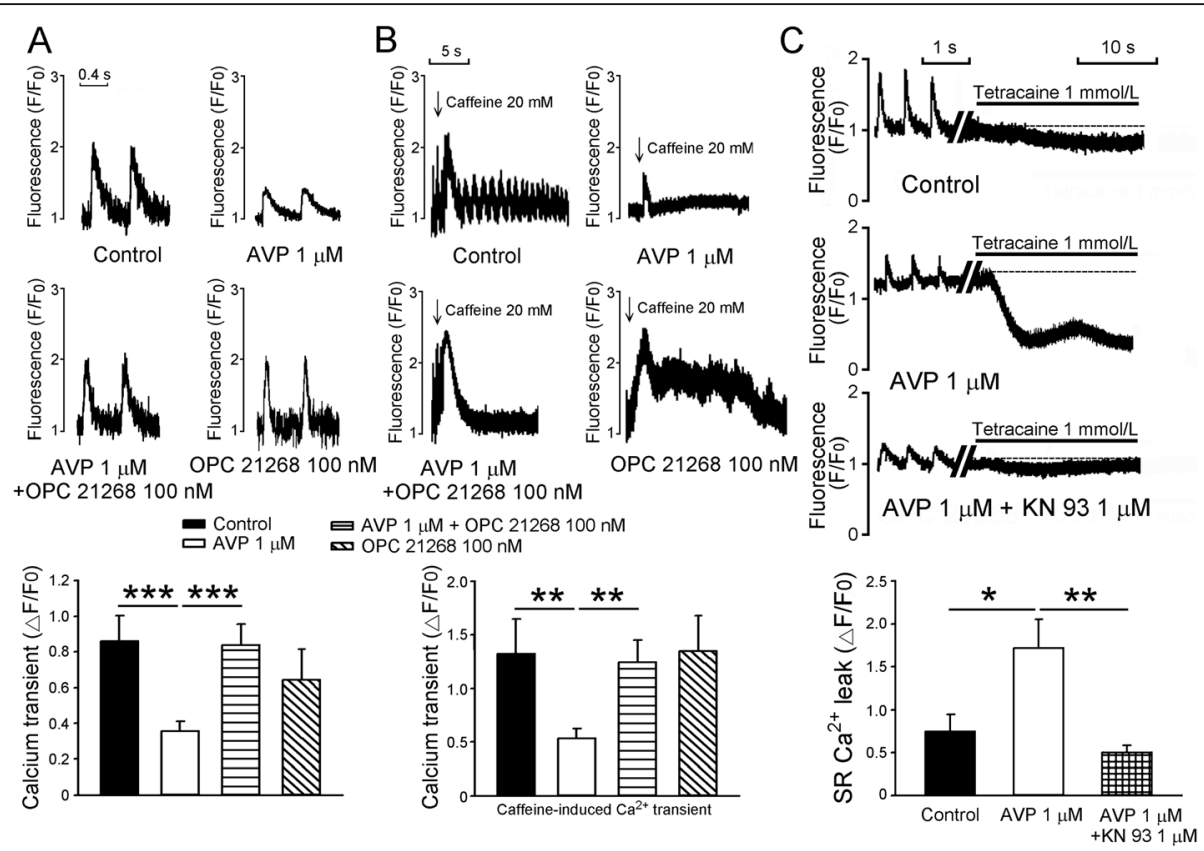

Fig. 4 Effects of arginine vasopressin (AVP) and its antagonist OPC 21268 on intracellular calcium $\left(\mathrm{Ca}^{2+}\right)$ homeostasis and sarcoplasmic reticulum (SR) $\mathrm{Ca}^{2+}$ leak in pulmonary vein (PV) cardiomyocytes. a An example and average data of $\mathrm{Ca}^{2+}{ }_{i}$ transients from control $(n=20), \mathrm{AVP}(1 \mu \mathrm{M})$ treated $(n=22)$, AVP $(1 \mu \mathrm{M})$ combined with OPC $21268(0.1 \mu \mathrm{M})$-treated $(n=25)$, and OPC $21268(0.1 \mu \mathrm{M})$-treated $(n=11)$ PV cardiomyocytes. b An example and average data of caffeine-induced $\mathrm{Ca}^{2+}{ }_{i}$ transients in control $(n=13)$ and PV cardiomyocytes treated with either $\mathrm{AVP}(1 \mu \mathrm{M}, n=15)$, AVP $(1 \mu \mathrm{M})$ plus OPC $21268(0.1 \mu \mathrm{M})(n=21)$, or OPC $21268(0.1 \mu \mathrm{M}, n=11)$. c An example and average data of SR Ca ${ }^{2+}$ leak from control $(n=14)$, AVP $(1 \mu \mathrm{M})$-treated $(n=16)$, and AVP $(1 \mu \mathrm{M})$ combined with KN-93 $(1 \mu \mathrm{M})$-treated $(n=10)$ PV cardiomyocytes. ${ }^{*} P<0.05 ;{ }^{* *} P<0.01 ;{ }^{* * *} P<0.005$

$\mathrm{Ca}^{2+}$ content in PV cardiomyocytes by the antagonist OPC 21268, suggests that this effect is mainly V1 signal dependent. Previous study has found that AVP can elicit $\mathrm{Ca}^{2+}$ entry through a receptor-mediated $\mathrm{Ca}^{2+}$-membrane non-selective cation channel in aortic smooth muscle cells, which regulates smooth muscle contractility and enhances vascular tone. OPC 21268 was noted to reverse AVP-induced activation of nonselective cation currents in aortic smooth muscle cells [48]. PVs contain vascular structure and cardiomyocytes. Previous studies have shown that stretch increased PV arrhythmogenesis through mechano-electrical feedback [49]. Therefore, $\mathrm{Ca}^{2+}$ influx through vasopressin-induced nonselective cation currents of PV smooth muscle cells may increase vascular stretch, further increasing PV arrhytmogenesis in vivo. In addition, the activity of vascular smooth muscle cells may influence the membrane potential of PV cardiomyocytes via intercellular transfer of electrical signals occurring between PV cardiomyocytes and vascular smooth myocytes of PVs, thereby exacerbating the propensity of PV arrhythmogenesis or cardiac dysrhythmias. Moreover, several previous studies have demonstrated the ability of caffeine to activate intermediate-conductance $\mathrm{Ca}^{2+}$-activated potassium channels [50-52], which are also functionally expressed in PV cardiomyocytes [53]. Therefore, part of caffeine-mediated changes in cytosolic $\mathrm{Ca}^{2+}$ transient could be secondarily attributed to its activation of these channels.

$\mathrm{SR} \mathrm{Ca}^{2+}$ leak, the release of small amounts of $\mathrm{Ca}^{2+}$, occurs when altered RyR spontaneously opens in diastole [54]. Diastolic $\mathrm{Ca}^{2+}$ release activates the forward mode of NCX current on the late diastolic depolarization. This late diastolic depolarization acceleration by NCX is required for the subsequent timely rapid AP upstroke $[55,56]$. In the present study, AVP increased forward mode of NCX as well as SR $\mathrm{Ca}^{2+}$ leak resulting steepness of late diastolic potential, which could be responsible for increasing automaticity [57]. Blocking AVP V1 receptor attenuated AVP-increased PV spontaneous activity, NCX and late diastolic potential, which implies AVP V1 receptor may play a role in AVP-increased PV spontaneous activity. In HF, RyR channels have increased singlechannel open probability, which results in diastolic SR $\mathrm{Ca}^{2+}$ leak and depletion of SR $\mathrm{Ca}^{2+}$ content, contributing to impaired contractility and HF progression [58, 59]. We found that AVP-treated PV cardiomyocytes had significantly larger SR $\mathrm{Ca}^{2+}$ leak than control cells. Clinically, greater $\mathrm{SR} \mathrm{Ca}^{2+}$ leak was well demonstrated in atrial myocytes in AF patients [44]. Greater $\mathrm{Ca}^{2+}$ leak may also contribute to a decrease in $\mathrm{Ca}^{2+}{ }_{\mathrm{i}}$ transients and $\mathrm{SR} \mathrm{Ca}{ }^{2+}$ content as well. CaMKII regulates several $\mathrm{Ca}^{2+}$-handling proteins and has been shown to be a central regulator of 

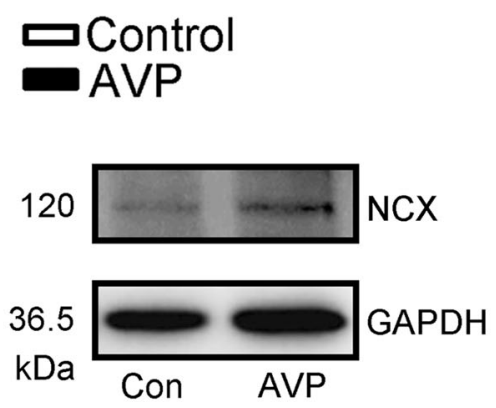

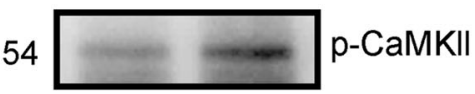

54
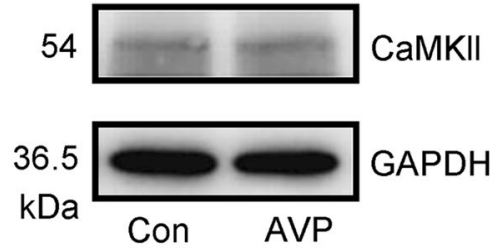
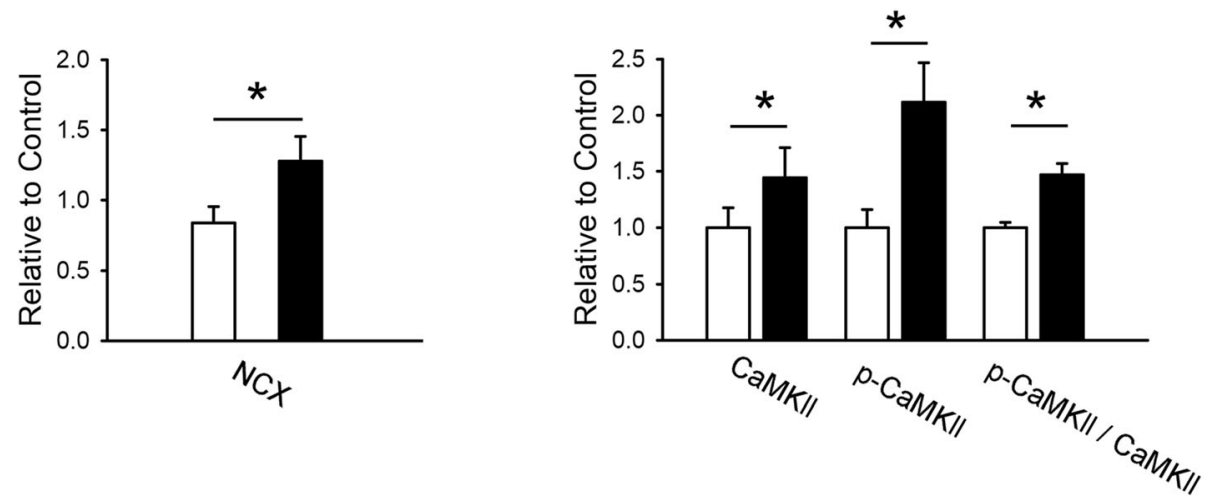

Fig. 5 Effects of arginine vasopressin (AVP) on sodium $\left(\mathrm{Na}^{+}\right) /$calcium $\left(\mathrm{Ca}^{2+}\right)$ exchanger (NCX) and $\mathrm{Ca}^{2+} / \mathrm{calmodulin}$-dependent protein kinase II (CaMKII) in pulmonary vein (PV) cardiomyocytes. Representative immunoblot and average data of $\mathrm{Na}^{+} / \mathrm{Ca}^{2+}$ exchanger ( $\mathrm{NCX}$ ), $\mathrm{Ca}^{2+} / \mathrm{calmodulin}^{-}$ dependent protein kinase II (CaMKII), and phosphorylated ratio of CaMKII from control $(n=6)$ and AVP $(1 \mu \mathrm{M})$-treated PV cardiomyocytes $(n=6) .{ }^{*} P<0.05$

excitation-contraction coupling [60], and increased CaMKII expression was found in AF [61]. CaMKII-dependent hyperphosphorylation of the RyR leads to elevated SR $\mathrm{Ca}^{2+}$ leak [61, 62], and triggers delayed afterdepolarization via activation of the NCX [63]. Diastolic SR $\mathrm{Ca}^{2+}$ leak can be amplified by NCX, triggering ectopic focal discharges or facilitating microreentry circuits promoting AF maintenance [64]. In this study, the higher pCaMKII in AVPtreated PV cardiomyocytes may result in the increased $\mathrm{Ca}^{2+}$ leak. The attenuation effects of KN-93 on AVPinduced $\mathrm{Ca}^{2+}$ leak in PV cardiomyocytes also suggests that activation of CaMKII is important for the effects of AVP on PV cardiomyocytes. In addition, the greater $\mathrm{I}_{\mathrm{Na}-\mathrm{Late}}$ in AVP-treated PV cardiomyocytes may also arise from the higher pCaMKII because activation of CaMKII is an important activator of $\mathrm{I}_{\mathrm{Na}-\text { Late. }}$. Enhanced $\mathrm{I}_{\mathrm{Na} \text {-Late }}$ Synergistically increases the risk of cardiac arrhythmias by the activation of CaMKII [17]. Accordingly, blocking the effects of AVP on PV cardiomyocytes may reduce the risk for HF-induced AF.

Our study may be limited in some respects. First, the PV cardiomyocytes received AVP for a relatively short time and AVP treatment of different duration may not have the same effects. Furthermore, AVP is usually associated with stress and pathological conditions. We only studied the effects of AVP on healthy PV cardiomyocytes, it is unclear whether our findings or theory applies to pathological settings such as HF. Finally, the details of the molecular regulation responsible for the effects of AVP in PV cardiomyocytes has not been fully elucidated.

\section{Conclusions}

AVP increases PV arrhythmogenesis with dysregulated $\mathrm{Ca}^{2+}$ homeostasis through vasopressin $\mathrm{V} 1$ signaling.

\section{Abbreviations}

AF: Atrial fibrillation; APs: Action potentials; AVP: Arginine vasopressin;

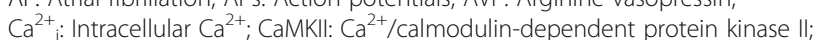
DAG: Diacylglycerol; GAPDH: Glyceraldehyde-3-phosphate dehydrogenase;

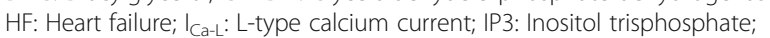
NCX: Sodium/calcium exchanger; NO: Nitric oxide; PAGE: Polyacrylamide gel by electrophoresis; PVs: Pulmonary veins; Rs: Series resistance; RyR: Ryanodine receptor; SDS: Sodium dodecyl sulfate; SR: Sarcoplasmic reticulum

\section{Acknowledgments}

Not applicable.

\section{Authors' contributions}

$J H H, Y Y L$ and YJC participated in the design and coordination of the study, performed experiments, analyzed data, and contributed to writing of the manuscript. YKL and SAC participated in the design and coordination of the study as well as helped to draft the manuscript. YCC performed experiments and analyzed data. All authors read and approved the final manuscript. 


\section{Funding}

This work was supported by grants from the Ministry of Science and Technology (MOST 103-2314-B-038-055, MOST107-2314-B-038-101-MY3, MOST107-2314-B-038-095, MOST107-2314-B-281-009, and MOST107-2314-B038-097-MY2), Taipei Medical University-Wan Fang Hospital (105-swf-02, 107wf-swf-02, and 107-wf-eva-13), Chi-Mei Medical Center (107CM-TMU-04 and CMNDMC10804), and the Ministry of National Defense-Medical Affairs Bureau, Taiwan (MAB-107-044)

\section{Availability of data and materials}

All data generated or analyzed during the current study are included in this published article.

\section{Ethics approval and consent to participate}

This study was approved by Institutional Animal Care and Use Committee at National Defense Medical Center, Taipei (IACUC-15-006).

\section{Consent for publication}

Not Applicable.

\section{Competing interests}

The authors declare that they have no competing interests.

\section{Author details}

${ }^{1}$ Division of Cardiovascular Medicine, Department of Internal Medicine, Wan Fang Hospital, Taipei Medical University, 111 Hsin-Lung Road, Sec. 3, Taipei 116, Taiwan. ${ }^{2}$ Department of Internal Medicine, School of Medicine, College of Medicine, Taipei Medical University, Taipei, Taiwan. ${ }^{3}$ Department of Biomedical Engineering, and Institute of Physiology, National Defense Medical Center, Taipei, Taiwan. ${ }^{4}$ Division of Cardiology, Department of Internal Medicine, Sijhih Cathay General Hospital, New Taipei City, Taiwan. ${ }^{5}$ School of Medicine, Fu-Jen Catholic University, New Taipei City, Taiwan. ${ }^{6}$ Heart Rhythm Center and Division of Cardiology, Department of Medicine, Taipei Veterans General Hospital, Taipei, Taiwan. ${ }^{7}$ Graduate Institute of Clinical Medicine, College of Medicine, Taipei Medical University, Taipei, Taiwan. ${ }^{8}$ Cardiovascular Research Center, Wan Fang Hospital, Taipei Medica University, Taipei, Taiwan.

Received: 29 March 2019 Accepted: 10 September 2019

\section{Published online: 17 September 2019}

\section{References}

1. Barrett LK, Singer M, Clapp LH. Vasopressin: mechanisms of action on the vasculature in health and in septic shock. Crit Care Med. 2007;35:33-40.

2. Chen X, Lu G, Tang K, Li Q, Gao X. The secretion patterns and roles of cardiac and circulating arginine vasopressin during the development of heart failure. Neuropeptides. 2015;51:63-73.

3. Holmes $\mathrm{CL}$, Landry DW, Granton JT. Science review: vasopressin and the cardiovascular system part 1--receptor physiology. Crit Care. 2003;7:427-34

4. Goldsmith SR, Francis GS, Cowley AW Jr, Levine TB, Cohn JN. Increased plasma arginine vasopressin levels in patients with congestive heart failure. J Am Coll Cardiol. 1983;1:1385-90.

5. Nakamura T, Funayama H, Yoshimura A, Tsuruya Y, Saito M, Kawakami M, Ishikawa SE. Possible vascular role of increased plasma arginine vasopressin in congestive heart failure. Int J Cardiol. 2006;106:191-5.

6. Costello-Boerrigter LC, Boerrigter G, Burnett JC Jr. Pharmacology of vasopressin antagonists. Heart Fail Rev. 2009;14:75-82.

7. Lu TL, Chang WT, Chan CH, Wu SN. Evidence for effective multiple K(+ )-current inhibitions by Tolvaptan, a non-peptide antagonist of vasopressin V2 receptor. Front Pharmacol. 2019;10:76.

8. Walker BR, Haynes JJ, Wang HL, Voelkel NF. Vasopressin-induced pulmonary vasodilation in rats. Am J Phys. 1989;257:H415-22.

9. Nemenoff RA. Vasopressin signaling pathways in vascular smooth muscle. Front Biosci. 1998:3:d194-207.

10. Henderson KK, Byron KL. Vasopressin-induced vasoconstriction: two concentration-dependent signaling pathways. J Appl Physiol (1985). 2007; 102:1402-9.

11. Mani BK, Brueggemann LI, Cribbs LL, Byron KL. Opposite regulation of KCNQ5 and TRPC6 channels contributes to vasopressin-stimulated calcium spiking responses in A7r5 vascular smooth muscle cells. Cell Calcium. 2009;45:400-11.
12. Lu YY, Cheng CC, Chen YC, Lin YK, Chen SA, Chen YJ. Electrolyte disturbances differentially regulate sinoatrial node and pulmonary vein electrical activity: a contribution to hypokalemia- or hyponatremia-induced atrial fibrillation. Heart Rhythm. 2016;13:781-8.

13. Weiss ML, Kenney MJ, Musch TI, Patel KP. Modifications to central neural circuitry during heart failure. Acta Physiol Scand. 2003;177:57-67.

14. Cheng Y, Pan T, Ge M, Chen T, Ye J, Lu L, Chen C, Zong Q, Ding Y, Wang D. Evaluation of vasopressin for Vasoplegic shock in patients with preoperative left ventricular dysfunction after cardiac surgery: a propensity-score analysis. Shock. 2018;50:519-24.

15. Personett HA, Stollings JL, Cha SS, Oyen L. Predictors of prolonged vasopressin infusion for the treatment of septic shock. J Crit Care. 2012;27:318 e7-12.

16. Chen YC, Lu YY, Cheng CC, Lin YK, Chen SA, Chen YJ. Sinoatrial node electrical activity modulates pulmonary vein arrhythmogenesis. Int J Cardiol. 2014:173:447-52.

17. Ma J, Luo A, Wu L, Wan W, Zhang P, Ren Z, Zhang S, Qian C, Shryock JC, Belardinelli L. Calmodulin kinase II and protein kinase C mediate the effect of increased intracellular calcium to augment late sodium current in rabbit ventricular myocytes. Am J Physiol Cell Physiol. 2012;302:C1141-51.

18. Lu YY, Wu WS, Lin YK, Cheng CC, Chen YC, Chen SA, Chen YJ. Angiotensin 1-7 modulates electrophysiological characteristics and calcium homoeostasis in pulmonary veins cardiomyocytes via MAS/PI3KeNOS signalling pathway. Eur J Clin Investig. 2018;48:e12854.

19. Chang SL, Chen YC, Yeh YH, Lin YK, Wu TJ, Lin Cl, Chen SA, Chen YJ. Heart failure enhanced pulmonary vein arrhythmogenesis and dysregulated sodium and calcium homeostasis with increased calcium sparks. J Cardiovasc Electrophysiol. 2011;22:1378-86.

20. Hussain A, Bennett R, Haqzad Y, Qadri S, Chaudhry M, Cowen M, Loubani M, Morice A. The differential effects of systemic vasoconstrictors on human pulmonary artery tension. Eur J Cardiothorac Surg. 2017;51:880-6.

21. Currigan DA, Hughes RJ, Wright CE, Angus JA, Soeding PF. Vasoconstrictor responses to vasopressor agents in human pulmonary and radial arteries: an in vitro study. Anesthesiology. 2014;121:930-6

22. Miyazaki T, Fujiki H, Yamamura Y. Tolvaptan, an orally active non-peptide arginine vasopressin V2 receptor antagonist, reduces ascites in rats with chronic liver injury. Hepatol Res. 2013;43:1224-30.

23. Tamma G, Di Mise A, Ranieri M, Geller A, Tamma R, Zallone A, Valenti G. The V2 receptor antagonist tolvaptan raises cytosolic calcium and prevents AQP2 trafficking and function: an in vitro and in vivo assessment. J Cell Mol Med. 2017;21:1767-80

24. Vasylyev DV, Waxman SG. Membrane properties and electrogenesis in the distal axons of small dorsal root ganglion neurons in vitro. J Neurophysiol. 2012;108:729-40.

25. Tse G. Mechanisms of cardiac arrhythmias. J Arrhythm. 2016;32:75-81.

26. Bogdanov KY, Maltsev VA, Vinogradova TM, Lyashkov AE, Spurgeon HA, Stern MD, Lakatta EG. Membrane potential fluctuations resulting from submembrane $\mathrm{Ca} 2+$ releases in rabbit sinoatrial nodal cells impart an exponential phase to the late diastolic depolarization that controls their chronotropic state. Circ Res. 2006;99:979-87.

27. Carmeliet E. Pacemaking in cardiac tissue. From IK2 to a coupled-clock system. Physiol Rep. 2019;7:e13862.

28. Ma J, Guo L, Fiene SJ, Anson BD, Thomson JA, Kamp TJ, Kolaja KL, Swanson $B J$, January $C T$. High purity human-induced pluripotent stem cell-derived cardiomyocytes: electrophysiological properties of action potentials and ionic currents. Am J Physiol Heart Circ Physiol. 2011;301:H2006-17.

29. Clancy CE, Tateyama M, Liu H, Wehrens XH, Kass RS. Non-equilibrium gating in cardiac $\mathrm{Na}+$ channels: an original mechanism of arrhythmia. Circulation. 2003;107:2233-7.

30. Zygmunt AC, Eddlestone GT, Thomas GP, Nesterenko W, Antzelevitch C. Larger late sodium conductance in $\mathrm{M}$ cells contributes to electrical heterogeneity in canine ventricle. Am J Physiol Heart Circ Physiol. 2001;281:H689-97.

31. Horvath B, Banyasz T, Jian Z, Hegyi B, Kistamas K, Nanasi PP, Izu LT, Chen-Izu $Y$. Dynamics of the late $\mathrm{Na}(+)$ current during cardiac action potential and its contribution to afterdepolarizations. J Mol Cell Cardiol. 2013;64:59-68.

32. Lu YY, Cheng CC, Tsai CF, Lin YK, Lee TI, Chen YC, Chen SA, Chen YJ. Discrepant effects of heart failure on electrophysiological property in right ventricular outflow tract and left ventricular outflow tract cardiomyocytes. Clin Sci (Lond). 2017;131:1317-27.

33. Ono K, Fozzard HA. Phosphorylation restores activity of L-type calcium channels after rundown in inside-out patches from rabbit cardiac cells. J Physiol. 1992;454:673-88. 
34. Lu YY, Chen YC, Kao YH, Wu TJ, Chen SA, Chen YJ. Extracellular matrix of collagen modulates intracellular calcium handling and electrophysiological characteristics of $\mathrm{HL}-1$ cardiomyocytes with activation of angiotensin II type 1 receptor. J Card Fail. 2011;17:82-90.

35. Sherpa RT, Mohieldin AM, Pala R, Wachten D, Ostrom RS, Nauli SM. Sensory primary cilium is a responsive CAMP microdomain in renal epithelia. Sci Rep. 2019;9:6523

36. Gutkowska J, Miszkurka M, Danalache B, Gassanov N, Wang D, Jankowski M. Functional arginine vasopressin system in early heart maturation. Am J Physiol Heart Circ Physiol. 2007;293:H2262-70.

37. Kaufmann JE, lezzi M, Vischer UM. Desmopressin (DDAVP) induces NO production in human endothelial cells via V2 receptor- and CAMP-mediated signaling. J Thromb Haemost. 2003;1:821-8.

38. Wasilewski MA, Myers VD, Recchia FA, Feldman AM, Tilley DG. Arginine vasopressin receptor signaling and functional outcomes in heart failure. Cell Signal. 2016;28:224-33

39. Reilly BA, Brostrom MA, Brostrom CO. Regulation of protein synthesis in ventricular myocytes by vasopressin. The role of sarcoplasmic/endoplasmic reticulum Ca2+ stores. J Biol Chem. 1998:273:3747-55.

40. Lin YK, Chen YC, Chen JH, Chen SA, Chen YJ. Adipocytes modulate the electrophysiology of atrial myocytes: implications in obesity-induced atrial fibrillation. Basic Res Cardiol. 2012;107:293.

41. Suenari K, Chen YC, Kao YH, Cheng CC, Lin YK, Chen YJ, Chen SA. Discrepant electrophysiological characteristics and calcium homeostasis of left atrial anterior and posterior myocytes. Basic Res Cardiol. 2011;106:65-74.

42. Sicouri S, Belardinelli $L$, Antzelevitch C. Antiarrhythmic effects of the highly selective late sodium channel current blocker GS-458967. Heart Rhythm. 2013;10:1036-43.

43. Schotten U, Greiser M, Benke D, Buerkel K, Ehrenteidt B, Stellbrink C, Vazquez-Jimenez JF, Schoendube F, Hanrath P, Allessie M. Atrial fibrillationinduced atrial contractile dysfunction: a tachycardiomyopathy of a different sort. Cardiovasc Res. 2002;53:192-201.

44. Hove-Madsen L, Llach A, Bayes-Genis A, Roura S, Rodriguez Font E, Aris A, Cinca J. Atrial fibrillation is associated with increased spontaneous calcium release from the sarcoplasmic reticulum in human atrial myocytes. Circulation. 2004;110:1358-63.

45. Huke S, Bers DM. Ryanodine receptor phosphorylation at serine 2030, 2808 and 2814 in rat cardiomyocytes. Biochem Biophys Res Commun. 2008;376:80-5.

46. Blaustein MP, Lederer WJ. Sodium/calcium exchange: its physiological implications. Physiol Rev. 1999;79:763-854

47. Wang D, Luo P, Wang Y, Li W, Wang C, Sun D, Zhang R, Su T, Ma X, Zeng C, Wang H, Ren J, Cao F. Glucagon-like peptide-1 protects against cardiac microvascular injury in diabetes via a CAMP/PKA/rho-dependent mechanism. Diabetes. 2013:62:1697-708.

48. Nakajima T, Hazama H, Hamada E, Wu SN, Igarashi K, Yamashita T, Seyama Y, Omata M, Kurachi Y. Endothelin-1 and vasopressin activate ca (2+)-permeable non-selective cation channels in aortic smooth muscle cells: mechanism of receptor-mediated Ca2+ influx. J Mol Cell Cardiol. 1996;28:707-22.

49. Chang SL, Chen YC, Chen YJ, Wangcharoen W, Lee SH, Lin Cl, Chen SA. Mechanoelectrical feedback regulates the arrhythmogenic activity of pulmonary veins. Heart. 2007:93:82-8.

50. Schroder RL, Jensen BS, Strobaek D, Olesen SP, Christophersen P. Activation of the human, intermediate-conductance, $\mathrm{Ca} 2+-$ activated $\mathrm{K}+$ channel by methylxanthines. Pflugers Arch. 2000:440:809-18.

51. Diaz P, Wood AM, Sibley CP, Greenwood SL. Intermediate conductance Ca2+-activated K+ channels modulate human placental trophoblast syncytialization. PLoS One. 2014;9:e90961.

52. Wulff H, Kolski-Andreaco A, Sankaranarayanan A, Sabatier JM, Shakkottai V. Modulators of small- and intermediate-conductance calcium-activated potassium channels and their therapeutic indications. Curr Med Chem. 2007;14:1437-57.

53. Chen WT, Chen YC, Lu YY, Kao YH, Huang JH, Lin YK, Chen SA, Chen YJ. Apamin modulates electrophysiological characteristics of the pulmonary vein and the sinoatrial node. Eur J Clin Investig. 2013;43:957-63.

54. Yano M, Yamamoto T, Kobayashi S, Matsuzaki M. Role of ryanodine receptor as a ca $(2)(+)$ regulatory center in normal and failing hearts. J Cardiol. 2009;53:1-7

55. Monfredi O, Maltsev VA, Lakatta EG. Modern concepts concerning the origin of the heartbeat. Physiology (Bethesda). 2013;28:74-92.
56. Lakatta EG, Maltsev VA, Vinogradova TM. A coupled SYSTEM of intracellular $\mathrm{Ca} 2+$ clocks and surface membrane voltage clocks controls the timekeeping mechanism of the heart's pacemaker. Circ Res. 2010;106:659-73.

57. Kim JJ, Yang L, Lin B, Zhu X, Sun B, Kaplan AD, Bett GC, Rasmusson RL, London $B$, Salama G. Mechanism of automaticity in cardiomyocytes derived from human induced pluripotent stem cells. J Mol Cell Cardiol. 2015;81:81-93.

58. Marx SO, Reiken S, Hisamatsu Y, Jayaraman T, Burkhoff D, Rosemblit N, Marks AR. PKA phosphorylation dissociates FKBP12.6 from the calcium release channel (ryanodine receptor): defective regulation in failing hearts. Cell. 2000;101:365-76.

59. Marks AR. Calcium cycling proteins and heart failure: mechanisms and therapeutics. J Clin Invest. 2013;123:46-52.

60. Maier LS, Bers DM. Role of Ca2+/calmodulin-dependent protein kinase (CaMK) in excitation-contraction coupling in the heart. Cardiovasc Res. 2007:73:631-40

61. Dobrev D, Wehrens XH. Calmodulin kinase II, sarcoplasmic reticulum Ca2+ leak, and atrial fibrillation. Trends Cardiovasc Med. 2010:20:30-4.

62. Neef S, Dybkova N, Sossalla S, Ort KR, Fluschnik N, Neumann K, Seipelt R, Schondube FA, Hasenfuss G, Maier LS. CaMKII-dependent diastolic SR Ca2+ leak and elevated diastolic Ca2+ levels in right atrial myocardium of patients with atrial fibrillation. Circ Res. 2010;106:1134-44.

63. Voigt N, Li N, Wang Q, Wang W, Trafford AW, Abu-Taha I, Sun Q, Wieland T, Ravens U, Nattel S, Wehrens XH, Dobrev D. Enhanced sarcoplasmic reticulum $\mathrm{Ca} 2+$ leak and increased $\mathrm{Na}+-\mathrm{Ca} 2+$ exchanger function underlie delayed afterdepolarizations in patients with chronic atrial fibrillation. Circulation. 2012:125:2059-70.

64. Dobrev D, Voigt N, Wehrens XH. The ryanodine receptor channel as a molecular motif in atrial fibrillation: pathophysiological and therapeutic implications. Cardiovasc Res. 2011;89:734-43.

\section{Publisher's Note}

Springer Nature remains neutral with regard to jurisdictional claims in published maps and institutional affiliations.
Ready to submit your research? Choose BMC and benefit from:

- fast, convenient online submission

- thorough peer review by experienced researchers in your field

- rapid publication on acceptance

- support for research data, including large and complex data types

- gold Open Access which fosters wider collaboration and increased citations

- maximum visibility for your research: over $100 \mathrm{M}$ website views per year

At $\mathrm{BMC}$, research is always in progress.

Learn more biomedcentral.com/submissions 